\title{
DASHBOARD INFORMATION UNTUK SISTEM NILAI KINERJA DOSEN DENGAN PENDEKATAN DATA CENTRIC
}

\author{
Hari Setiaji \\ Jurusan Teknik Informatika \\ Universitas Islam Indonesia \\ hari.setiaji@uii.ac.id
}

\begin{abstract}
Nilai Kinerja Dosen (NKD) system in higher education institutions can help managers to monitor the teacher learning activity periodically. The information generated by NKD system is limited with statistical data only and with text content only. This study observed the data output from the NKD system can be processed into more valuable information and have good information visualization. One part of this research is develop a dashboard information prototype with datacentric approach. The selection of data-centric approach for quantity and variety factors of data that are found can be visualized. This study found that interactivity and analytical factors in NKD dashboard information not quite satisfy users who are top level.
\end{abstract}

Keyword: dashboard, dashboard prototype, data-centric, sistem nilai kinerja dosen

\section{Pendahuluan}

Undang Undang (UU) Nomor 14 Tahun 2005 tentang Guru dan Dosen dan Peraturan Pemerintah Republik Indonesia Nomor 37 Tahun 2009 tentang Dosen menyatakan bahwa dosen adalah pendidik profesional dan ilmuwan dengan tugas utama mentransformasikan, mengembangkan dan menyebarluaskan ilmu pengetahuan, teknologi, dan seni melalui pelaksanaan Tridharma Perguruan Tinggi, meliputi pendidikan dan pengajaran, penelitian, dan pengabdian kepada masyarakat, serta kegiatan penunjang tridharma lainnya [1], [2]. Keputusan Direktur Jenderal Pendidikan Tinggi Departemen Pendidikan Dan Kebudayaan Republik Indonesia Nomor 48/D3/Kep/1983 tentang Beban Tugas Tenaga Pengajar Pada Perguruan Tinggi menyatakan bahwa beban kerja dosen dalam melaksanakan tugas utama Tridharma Perguruan Tinggi paling sedikit sepadan dengan 12 (dua belas) SKS (satuan kredit semester) dan paling banyak 16 (enam belas) SKS pada setiap semester sesuai dengan kualifikasi akademiknya.

Untuk meningkatkan akuntabilitas pada para pemangku kepentingan, maka beban kerja dan kinerja dosen harus diadministrasikan dan dievaluasi secara periodik sebagai bentuk akuntabilitas perguruan tinggi kepada para pemangku kepentingan (stake holder), dengan tujuan meningkatkan profesionalisme dosen dalam melaksanakan tugas, meningkatkan proses dan hasil pendidikan, menilai akuntabilitas kinerja dosen, meningkatkan atmosfer akademik dan mempercepat terwujudnya tujuan pendidikan nasional [3].

Fakultas Teknologi Industri telah menerapkan sistem NKD (Nilai Kinerja Dosen) sebagai sistem yang mengevaluasi kinerja dosen dari tahun ajaran 2010/2011 di setiap jurusan yang bernaung di dalamnya. NKD merupakan pengejawantahan aspek penilaian yang telah ditetapkan oleh fakultas. Beberapa aspek yang menjadi tolak ukur untuk penilaian kinerja dosen antara lain: 
kuesioner mahasiswa, kehadiran mengajar dosen, jabatan akademik dosen, dan pengumpulan koreksi ujian.

Sistem NKD merupakan sistem yang digunakan untuk mengevaluasi aktivitas pembelajaran yang dilakukan oleh dosen selama rentang waktu mengajar tertentu. Pada awalnya penilaian kinerja dosen hanya diukur berdasarkan kuesioner yang diberikan kepada mahasiswa kelas yang diampu oleh dosen yang bersangkutan. Materi kuesioner yang diberikan kepada mahasiswa yaitu proses transfer knowledge pembelajaran dan tools pendukung pembelajaran. Dengan demikian, penilaian kinerja dosen hanya bertumpu pada satu aspek penilaian yaitu pembelajaran di kelas.

Dalam rentang waktu penggunaan NKD di Fakultas Teknologi Industri, pola penggunaan sistem hanya bertumpu kepada operator dan administrator sistem sebagai pengguna utama NKD. Administrator bertugas untuk membuat tahun ajaran baru dan mengeset aspek-aspek penilaian NKD. Sedangkan, operator akan melakukan masukan data dari setiap dosen yang mengampu pada tahun ajaran tersebut. Mekanisme pelaporan hasil keluaran dari sistem NKD yaitu administrator mengolah dan melakukan validasi hasil keluaran berdasarkan masukan dari operator kemudian melaporkannya kepada fakultas dan semua jurusan di lingkungan Fakultas.

Hasil keluaran dari NKD adalah nilai kinerja dosen yang mendefinisikan nilai dari tiap aspek yang telah ditetapkan oleh Fakultas di rentang waktu tahun ajaran tertentu. Bentuk keluaran berupa konten text dan dokumen yang berisi nilai statistik kinerja yang merupakan hasil pengolahan dari tiap aspek. Hasil keluaran ini hanya dapat diakses oleh administrator sistem kemudian dilaporkan secara fisik kepada ketua prodi dan pejabat fakultas yang berwenang.

Ketiadaan akses pada sistem NKD bagi masing-masing prodi dan pejabat fakultas membuat proses bisnis pelaporan menjadi sangat bergantung kepada administrator sistem. Dibutuhkan sebuah penambahan fungsionalitas pada sistem NKD terutama dalam hal akses bagi aktor prodi dan fakultas yang berperan dalam penggunaan hasil akhir keluaran sistem. Fungsionalitas yang diberikan bagi aktor prodi dan fakultas merupakan kompilasi hasil keluaran yang diterapkan dalam bentuk dashboard view.

\section{Metode Penelitian}

\subsection{Landasan Teori}

\section{A. Dashboard}

Salah satu bentuk aplikasi komputer yang umum digunakan dalam mendukung pengambilan keputusan adalah dashboard system. Menurut [4], dashboard pada dasarnya adalah nama baru untuk Executive Information System yang dikembangkan pertama kali pada tahun 1980an. Pada awal pengembangannya, dashboard mengalami fase hibernasi disebabkan karena metode pendukung penyediaan data yaitu data ware-housing dan business intelligence belum berevolusi untuk menyediakan metodologi penanganan datanya. Hibernasi ini berlangsung sampai ketika metodologi data warehousing dan business intelligence menjadi cukup matang di tahun 2000an [4].

Setelah melalui serangkaian penelitian, [4] kemudian mendefinisikan dashboard sebagai sebuah tampilan visual dari informasi penting yang dibutuhkan untuk mencapai satu tujuan atau lebih. Tampilan tersebut dikonsolidasikan dan ditata dalam satu layar sehingga informasi yang ada dapat dimonitor dalam satu kali lihat. Ada beberapa macam tipe dari dashboard, menurut [5] mengemukakan tiga buah tipe dashboard, yaitu: 
a. Dashboard Strategis

Dashboard strategis digunakan untuk mendukung level manajemen level strategis untuk memberikan informasi dalam membuat keputusan bisnis, memprediksi peluang, dan memberikan arahan pencapaian tujuan strategis.

b. Dashboard Taktis

Dashboard tipe ini berfokus pada proses analisis untuk menentukan penyebab dari suatu kondisi atau kejadian tertentu.

c. Dashboard Operasional

Dashboard operasional berfungsi sebagai pendukung monitoring dari aktivitas proses bisnis yang spesifik. Fokus pada monitoring aktivitas dan kejadian yang tidak berubah secara konstan.

\section{Karakteristik Dashboard}

Dashboard merupakan salah satu solusi dalam penyajian dan visualisasi data dengan menggunakan sistem dashboard, data dan informasi strategis dapat ditampilkan dengan cepat, on line, dan mudah dipahami oleh pemimpin organisasi [6]. Dashboard memiliki beberapa karakteristik mendasar, Shadan Malik menyatakan karakteristik dashboard dalam akronim S-M-AR-T (Synergetic, Monitor, Accurate, Responsive, Timely) dan I-M-P-A-C-T (Interactive, More Data history, Personalized, Analytical, Collaborative, Trackability) [7]. Penjelasan mengenai karakteristik tersebut dapat dilihat pada Tabel 1 berikut.

Tabel 1. Karakteristik Dashboard [7]

\begin{tabular}{|l|l|}
\hline Karakteristik & Penjelasan \\
\hline Synergetic & $\begin{array}{l}\text { Ergonomis dan memiliki tampilan visual yang mudah dipahami oleh } \\
\text { pengguna. Dashboard menyinergikan informasi dari berbagai aspek } \\
\text { berbeda dalam satu layar. }\end{array}$ \\
\hline Monitor & $\begin{array}{l}\text { Menampilkan kinerja yang diperlukan dalam pembuatan keputusan } \\
\text { dalam domain tertentu, sesuai dengan tujuan pembangunan } \\
\text { dashboard tersebut. }\end{array}$ \\
\hline Accurate & $\begin{array}{l}\text { Informasi yang disajikan harus akurat, dengan tujuan untuk } \\
\text { mendapatkan kepercayaan dari penggunannya. }\end{array}$ \\
\hline Responsive & $\begin{array}{l}\text { Merespon threshold yang telah didefinisikan, dengan memberikan } \\
\text { alert (seperti bunyi alarm, blinker, email) untuk mendapatkan } \\
\text { perhatian pengguna terhadap hal-hal yang kritis. }\end{array}$ \\
\hline Timely & $\begin{array}{l}\text { Menampilkan informasi terkini yang diperlukan untuk pengambilan } \\
\text { keputusan. }\end{array}$ \\
\hline Interactive & $\begin{array}{l}\text { Pengguna dapat melakukan drill down dan mendapatkan informasi } \\
\text { yang lebih detail, analisis sebab akibat dan sebagainya. }\end{array}$ \\
\hline More Data history & $\begin{array}{l}\text { Pengguna dapat melihat tren sejarah dari kinerja, misalkan melihat } \\
\text { perbandingan market share periode saat ini dengan beberapa tahun } \\
\text { yang lalu, untuk mengetahui apakah kondisi sekarang lebih baik atau } \\
\text { tidak. }\end{array}$ \\
\hline Personalized & $\begin{array}{l}\text { Penyajian informasi harus spesifik untuk setiap jenis pengguna sesuai } \\
\text { dengan domain tanggung jawab, hak akses, dan batasan akses data. }\end{array}$ \\
\hline Memberikan fasilitas bagi pengguna untuk melakukan analisis seperti \\
\hline
\end{tabular}




\begin{tabular}{|l|l|}
\hline & analisis sebab akibat. \\
\hline Collaborative & $\begin{array}{l}\text { Memberikan fasilitas pertukaran catatan (laporan) antar pengguna } \\
\text { mengenai hasil pengamatan dashboardnya masing-masing sebagai } \\
\text { saran untuk komunikasi dalam rangka melakukan fungsi manajemen } \\
\text { dan kontrol. }\end{array}$ \\
\hline Trackability & $\begin{array}{l}\text { Memungkinkan setiap pengguna untuk mengkustomisasi metrik yang } \\
\text { akan dilacaknya. }\end{array}$ \\
\hline
\end{tabular}

Menurut Novell terdapat empat kriteria utama yang harus dimiliki oleh dashboard. Diantaranya sebagai berikut [8]:

a. Mengonsolidasikan informasi bisnis yang relevan dan menyajikan dalam satu kesatuan pandangan.

b. Informasi yang disampaikan harus akurat secara tepat waktu.

c. Memberikan akses yang aman terhadap informasi yang sensitif. Dashboard harus memiliki mekanisme pengaman, agar data atau informasi tidak diberikan pada pihak yang tidak berkepentingan.

d. Memberikan solusi yang komprehensif. Dashboard bisa memberikan solusi secara menyeluruh tentang domain permasalahan yang ditanganinya.

\section{Information Visualization}

Pada awalnya representasi secara visual terhadap data kuantitatif digunakan dalam berbagai bidang ilmiah dan ditampilkan dalam bentuk publikasi cetak. Representasi visual dalam bentuk grafik dengan tipe grafik garis dan grafik batang ditemukan oleh ilmuwan dalam bidang sosial William Playfair pada akhir abad 18. Edward Tufte memberikan terobosan dengan menguraikan prinsip-prinsip kunci dalam menampilkan representasi visual yang efektif terhadap informasi kuantitatif. Edward Tufte juga mengidentifikasi kesalahan umum yang dapat mengaburkan data dalam representasi visual serta memberikan alternatif desain yang efektif dan jelas untuk menampilkan bentuk data kuantitatif [9].

Card et al mendefinisikan Information Visualization sebagai "the use of computer-supported, interactive, visual representation of abstract data to amplify cognition" [10]. Konsep dasar dari representasi secara visual adalah kemampuannya dalam memanfaatkan kemampuan persepsi manusia dalam mempercepat proses penerimaan informasi. Secara tradisional, information visualization telah difokuskan pada bidang ilmu pengetahuan, karena pada bidang ini menghasilkan sejumlah data berukuran besar yang bersifat terstruktur dan seringkali data numeris. Representasi visual memungkinkan peneliti untuk mengeksplorasi adan melakukan analisis terhadap data tersebut, sehingga dapat mengomunikasikan hasil penemuan mereka terhadap bidang lain [9].

\section{Penilaian Kinerja Dosen}

Proses penilaian kinerja dosen pada tiap semester dicatat dan direkam dalam sebuah sistem NKD (Nilai Kinerja Dosen). Faktor penilaian yang menjadi parameter dalam sistem NKD meliputi aktivitas pembelajaran yang dilakukan oleh dosen dalam satu semester. Berdasarkan Gambar 1 terdapat empat buah faktor penilaian yang menjadi dasar nilai kinerja dosen, pengategorian parameter penilaian dibedakan berdasarkan status dosen yakni Dosen Tetap dan Dosen Tidak Tetap. 


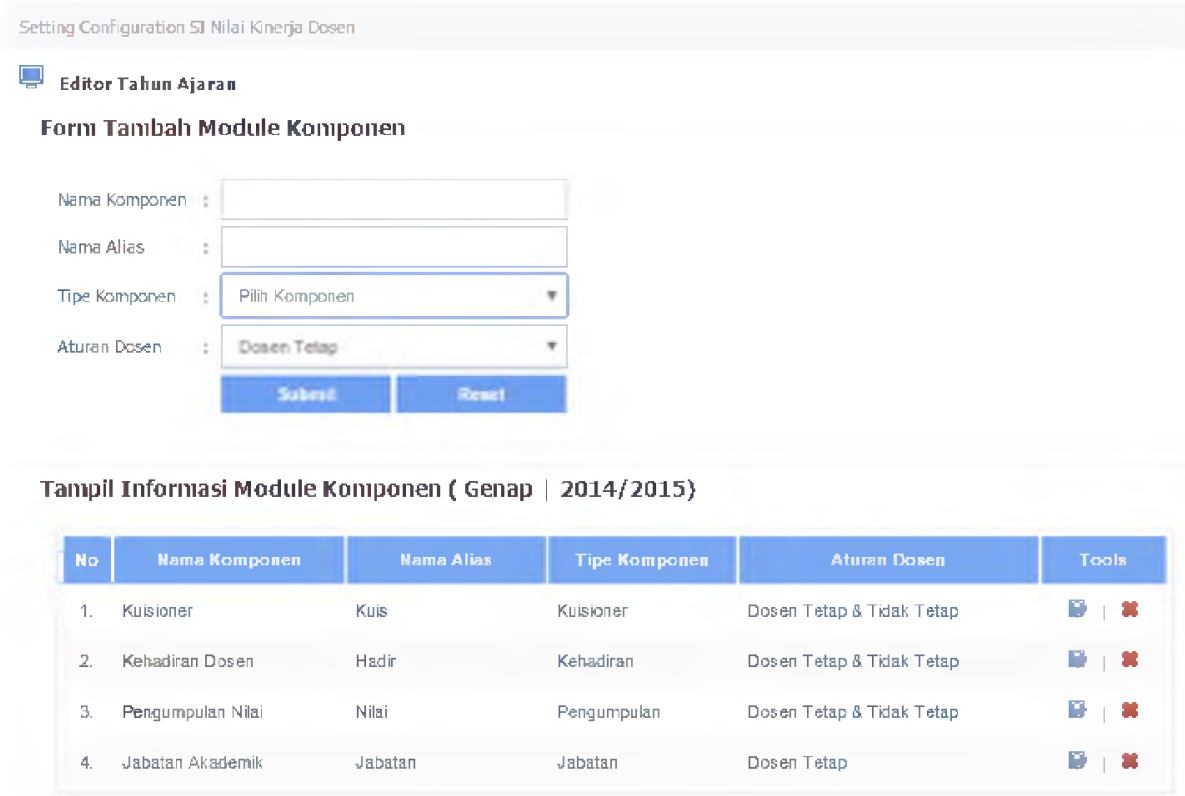

Gambar 1. Pengaturan Modul/Parameter Penilaian Dosen

Perbedaan kategori dosen memiliki pengaruh persentase komponen yang akan diberlakukan pada dosen tersebut. Terdapat perbedaan komponen serta persentase untuk dosen tetap dan dosen tidak tetap, perbedaan komponen dan persentase dapat dilihat pada Gambar 2. Pengaturan komponen dan persentase berlaku dinamis pada tiap semester sesuai dengan kebijakan dari pihak Fakultas. Faktor-faktor penilaian dosen antara lain:

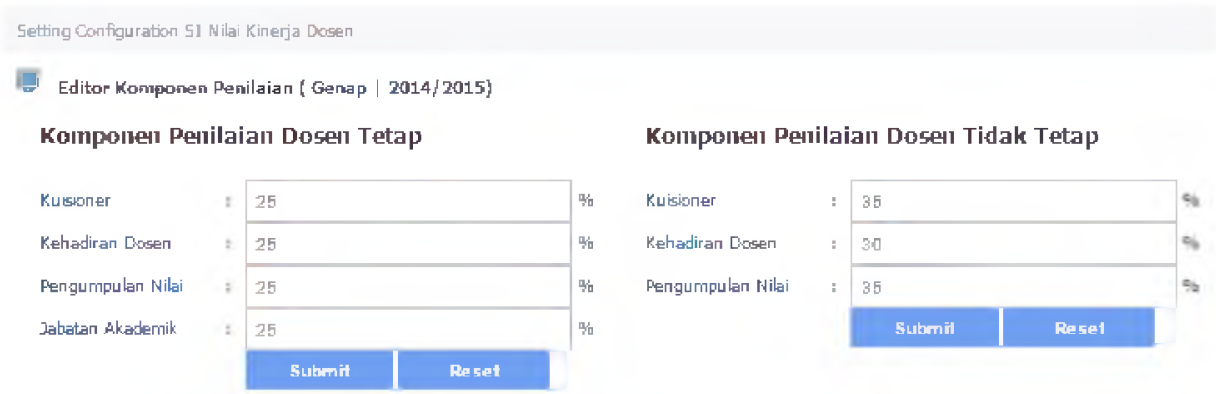

Gambar 2. Pengaturan Persentase Komponen Penilaian

1. Kuesioner

Komponen penilaian berdasarkan kuesioner merupakan proses penilaian yang berasal dari pengisian kuesioner mahasiswa. Konten kuesioner bersifat dinamis tiap semester jika terdapat perubahan kebijakan konten dari pejabat berwenang. Sistem NKD akan mencatat hasil kuesioner dari tiap mahasiswa untuk di rekapitulasi sesuai dengan kelas mengajar dosen yang akan dinilai.

2. Kehadiran

Komponen kehadiran dosen akan merangkum kehadiran tatap muka dosen di kelas selama satu semester. Terdapat beberapa kriteria kehadiran yang akan disesuaikan dengan nilai bobot penilaian kehadiran berdasarkan kebijakan pihak Fakultas. 


\section{Pengumpulan}

Komponen pengumpulan merupakan kriteria yang akan mencatat waktu pengumpulan hasil koreksi ujian akhir semester dari tiap dosen per-matakuliah. Pengaturan pengumpulan memiliki beberapa kriteria yang mendeskripsikan bobot waktu pengumpulan nilai yang telah ditentukan. Secara global terdapat dua pengaturan dasar yakni range hari pengumpulan dan jumlah mahasiswa pada kelas yang diampu. Secara spesifik, pengaturan berlaku pada tiap kelas matakuliah dengan mendefinisikan waktu maksimal batas pengumpulan nilai akhir mahasiswa.

4. Jabatan

Komponen jabatan merupakan representasi dari jenjang studi dari dosen dan berapa lama waktu jenjang studi tersebut berlaku bagi dosen bersangkutan. Komponen ini akan mengecek pembaharuan jenjang studi dari tiap dosen pada tiap semester kemudian menyesuaikan nilai kinerja sesuai dengan pengaturan range waktu yang telah ditentukan.

\section{Analisis Referensi Metodologi}

Secara umum, ada dua pendekatan yang digunakan dalam pembangunan perangkat lunak, khususnya dashboard, yaitu data-centric dan user-centric [11]. Kedua pendekatan ini memiliki perbedaan mendasar. Pendekatan data-centric menekankan pada aktivitas pembuatan model dan struktur data, yang digunakan sebagai dasar dalam membangun kode program dan desain antarmuka. Sedangkan pendekatan user-centric menekankan pada pembangunan antarmuka melalui perancangan prototype, dengan fokus pada kebutuhan dan selera pengguna [11]. Berikut Tabel 2 yang mendeskripsikan perbedaan dari kedua pendekatan tersebut.

Tabel 2. Pendekatan Data-Centric dengan User-Centric

\begin{tabular}{|l|l|}
\hline Data-Centric & User-Centric \\
\hline Menggunakan pendekatan bottom-up & Menggunakan pendekatan top-down \\
\hline Fokus pada hal-hal teknis, yaitu data. & $\begin{array}{l}\text { Fokus pada kebutuhan dan selera } \\
\text { pengguna }\end{array}$ \\
\hline $\begin{array}{l}\text { Dimulai dengan identifikasi data yang } \\
\text { digunakan dalam proses bisnis. }\end{array}$ & $\begin{array}{l}\text { Dimulai dengan identifikasi informasi } \\
\text { mengenai kebutuhan pengguna, seperti } \\
\text { informasi apa yang perlu disajikan, } \\
\text { kepada siapa informasi diberikan, dan } \\
\text { seberapa detail informasi tersebut perlu } \\
\text { untuk disampaikan. }\end{array}$ \\
\hline $\begin{array}{l}\text { Menekankan pada aktivitas pembuatan } \\
\text { model data dan struktur data. }\end{array}$ & $\begin{array}{l}\text { Menekankan antavitas } \\
\text { pengembangan antarmuka pengguna, } \\
\text { melalui perancangan prototype. }\end{array}$ \\
\hline $\begin{array}{l}\text { Desain antarmuka dan kontrol navigasi } \\
\text { dilakukan dengan mengikuti struktur data } \\
\text { yang dibuat. }\end{array}$ & $\begin{array}{l}\text { Model data mengikuti desain prototype } \\
\text { yang telah dibuat. Pembuatan struktur } \\
\text { data dilakukan melalui teknik filtering } \\
\text { dan summarizing. }\end{array}$ \\
\hline $\begin{array}{l}\text { Menghasilkan struktur tabel yang efisien. } \\
\text { Menghasilkan struktur tabel yang tidak } \\
\text { efisien. }\end{array}$ \\
\hline Bertujuan menyediakan akses secara cepat \\
Bertujuan membuat sistem yang \\
\hline
\end{tabular}




\begin{tabular}{|l|l|}
\hline $\begin{array}{l}\text { ke data tertentu saja, yang diperlukan oleh } \\
\text { pengguna. }\end{array}$ & $\begin{array}{l}\text { menyajikan data dan informasi, yang } \\
\text { mudah dipahami oleh pengguna. }\end{array}$ \\
\hline
\end{tabular}

Dashboard merupakan alat yang mengandalkan antarmuka visual dalam menyajikan informasi di dalamnya. Antarmuka yang sesuai dengan kebutuhan informasi pengguna merupakan kunci keberhasilan dashboard. Informasi yang disajikan pada dashboard harus dapat dipahami secara cepat dan menimbulkan persepsi yang benar oleh penggunanya. Pendekatan data-centric yang memfokuskan pada perancangan antarmuka sesuai dengan ketersediaan data yang powerfull dianggap dapat menampilkan informasi yang tepat dan cepat kepada penggunanya.

Berdasarkan hasil analisis tersebut, diperlukan sebuah metodologi yang menjelaskan secara detail tahapan dalam pembangunan dashboard, beserta dengan kakas yang digunakan pada setiap tahapan. Metodologi yang dibuat pada penelitian ini mengadopsi pendekatan data-centric untuk membangun desain antarmuka dashboard yang sesuai dengan kebutuhan informasi pengguna sesuai dengan pengolahan data yang telah ada di sistem. Metodologi difokuskan pada tahap identifikasi kebutuhan data/informasi, perencanaan, dan perancangan prototype dashboard.

\section{Kerangka Berpikir dan Metodologi}

Menurut [12] prinsip-prinsip pembangunan dashboard menunjukkan bahwa ada tiga aspek utama yang harus dipenuhi oleh sebuah dashboard yaitu data/informasi, personalisasi, dan kolaborasi dashboard. Ketiga aspek tersebut digunakan sebagai dasar dalam membuat kerangka berpikir metodologi pembangunan dashboard, dengan memetakan setiap aspek ke dalam tahapan pengembangan sistem perangkat lunak. Kerangka berpikir metodologi pembangunan dashboard berdasarkan kerangka berpikir [12] dapat dilihat pada Gambar 1 berikut.

\begin{tabular}{|c|c|c|c|}
\hline Talbap Aspek & & Personalisasi & Kolaborasi \\
\hline $\begin{array}{l}\text { Identifikasi } \\
\text { kebutuhan }\end{array}$ & $\begin{array}{l}\text { Identifikasi kebutuhan } \\
\text { data dan informasi. }\end{array}$ & $\begin{array}{l}\text { Identifikasi jenis } \\
\text { dasliboard dan kelompok } \\
\text { pengguna. }\end{array}$ & $\begin{array}{l}\text { Identifikasi abstraksi } \\
\text { skenario(high level } \\
\text { scenano) dashboard. }\end{array}$ \\
\hline & $\begin{array}{l}\text { - Analisis nueta- } \\
\text { informasi dan konten } \\
\text { informasi. } \\
\text { - Perbaikan sumber data. }\end{array}$ & $\begin{array}{l}\text { Perencanaan } \\
\text { futigsionalitas dashboard. }\end{array}$ & $\begin{array}{l}\text { Perencanaan hierarkhi } \\
\text { kotnunikasi penggutua. }\end{array}$ \\
\hline $\begin{array}{l}\text { Perancangan } \\
\text { prototype }\end{array}$ & $\begin{array}{l}\text { Perancangan konten } \\
\text { informasi dashboard. }\end{array}$ & $\begin{array}{l}\text { Peratcangan desain dan } \\
\text { layout dashboard. }\end{array}$ & $\begin{array}{l}\text { Perancangan mekanisme } \\
\text { komunikasi danz narigasi. }\end{array}$ \\
\hline $\begin{array}{l}\text { Review } \\
\text { Prototype }\end{array}$ & \multicolumn{3}{|c|}{ Review dan perbaikan prototype } \\
\hline $\begin{array}{l}\text { Implementasi } \\
\text { dashboard }\end{array}$ & \multicolumn{3}{|c|}{$\begin{array}{l}\text { - Implementasi prototype. } \\
\text { - Integrasi cengan data sumber. } \\
\text { - Penerapan kontrol security } \\
\text { - Validasi dan pengujian sistem. }\end{array}$} \\
\hline Deploynent & \multicolumn{3}{|c|}{$\begin{array}{l}\text { - Penerapan ke lingkungan operasionalnya. } \\
\text { - Integrasi sistem dengan lingkungan operasionalnya. } \\
\text { - Sosialisasi dan pelatihan penggunaan dashboard. }\end{array}$} \\
\hline Maintenance & \multicolumn{3}{|c|}{$\begin{array}{l}\text { Pemeliharaan dan perbaikan da shboard agar tetap sesuai dengan kebutuhan bisnis } \\
\text { dan organisasi }\end{array}$} \\
\hline
\end{tabular}

Gambar 3. Kerangka Berpikir Metodologi Pembangunan Dashboard [12].

Sesuai dengan tahapan yang telah digambarkan pada Gambar 1, terdapat empat buah tahapan yang akan digunakan untuk membuat metodologi pembangunan dashboard secara utuh dan runtun. Metodologi yang dirancang akan menjelaskan tahapan pembuatan dashboard beserta dengan masukan yang diperlukan, proses yang dikerjakan, keluaran yang dihasilkan, dan kakas yang 
digunakan. Gambar 2 menujukkan metodologi yang digunakan pada penelitian ini dalam membangun dashboard view dengan mengadopsi metodologi pembangunan dashboard berdasarkan kerangka berpikir yang telah dijelaskan sebelumnya.

\section{Analisis Konten dan Hierarki}

Pada tahap analisis konten dan hierarki informasi dilakukan dengan mengkaji dokumen metainformasi dan dokumen fungsionalitas dashboard. Pada tahap ini, analisis akan difokuskan pada pembangunan dashboard untuk kepentingan pejabat level prodi dan fakultas.

Dashboard yang digunakan oleh pejabat prodi dan fakultas menyajikan informasi yang menyatakan kondisi kinerja pembelajaran dosen secara keseluruhan terkait parameter yang telah ditentukan. Tampilan dashboard pada level fakultas akan menampilkan pencapaian kinerja dari tiap prodi unit kerja. Sedangkan pada level prodi, akan ditambahkan tampilan mengenai data dosen secara individu, informasi yang disajikan, jenis media yang digunakan, dan cara perhitungan summary untuk setiap konten informasi pada dashboard fakultas dan prodi dapat dilihat pada Tabel 4 dan Tabel 5.

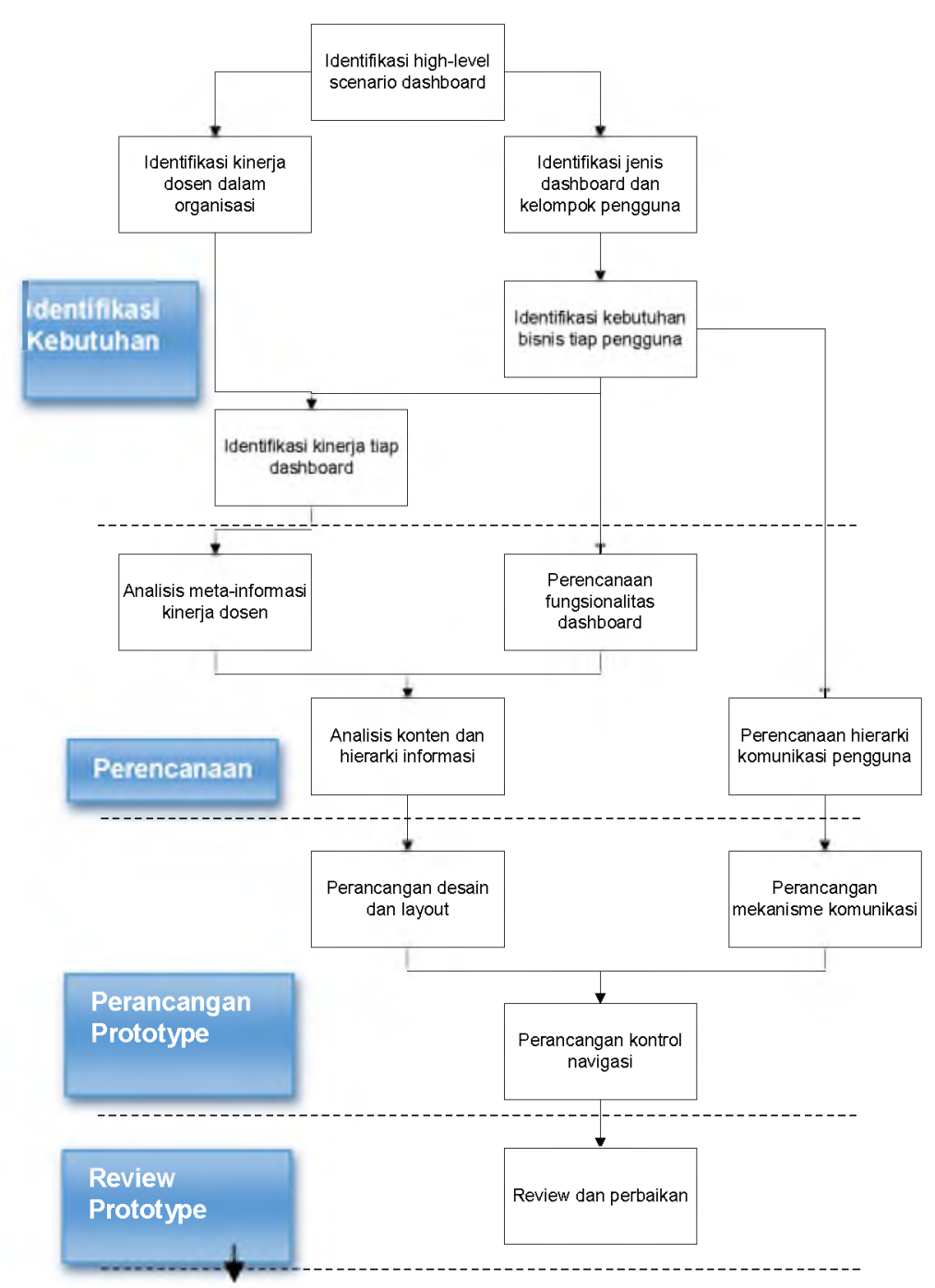

Gambar 4. Metodologi Pengembangan Dashboard 
Tabel 4. Konten Informasi Dashboard Fakultas

\begin{tabular}{|c|l|l|l|}
\hline No & Konten Informasi & \multicolumn{1}{|c|}{ Output } & \multicolumn{1}{c|}{ Perhitungan } \\
\hline 1 & Unit Kerja & List & $\begin{array}{l}\text { Menampilkan seluruh prodi yang telah } \\
\text { di-input ke sistem, ditambah unit kerja } \\
\text { utama yaitu fakultas. }\end{array}$ \\
\hline 2 & Tahun Ajaran & List & $\begin{array}{l}\text { Menampilkan dalam periode satu } \\
\text { tahun dengan mengalkulasi 2 semester } \\
\text { dalam 1 tahun ajaran. }\end{array}$ \\
\hline 3 & Dosen & $\begin{array}{l}\text { Scroll List } \\
\text { Bar }\end{array}$ & $\begin{array}{l}\text { Menampilkan list dosen sesuai dengan } \\
\text { unit kerja yang dipilih, ditambah } \\
\text { pilihan keseluruhan dosen untuk } \\
\text { melihat summary secara menyeluruh. }\end{array}$ \\
\hline 4 & Performa Kinerja & $\begin{array}{l}\text { Gauge } \\
\text { Chart }\end{array}$ & $\begin{array}{l}\text { Rata-rata kinerja dari tiap parameter } \\
\text { seluruh dosen se-fakultas untuk tahun } \\
\text { ajaran terkini. }\end{array}$ \\
\hline 5 & $\begin{array}{l}\text { History Performa } \\
\text { Kinerja }\end{array}$ & $\begin{array}{l}\text { Mooltips } \\
\text { Line Chart }\end{array}$ & $\begin{array}{l}\text { Rattiple } \\
\text { seluruh dosen fakultas untuk tahun } \\
\text { terkini dan tiga tahun sebelumnya. }\end{array}$ \\
\hline 6 & $\begin{array}{l}\text { Performa Tiap Unit } \\
\text { Kerja }\end{array}$ & $\begin{array}{l}\text { Multiple } \\
\text { Bar Chart }\end{array}$ & $\begin{array}{l}\text { Rata-rata kinerja dari tiap parameter } \\
\text { untuk tiap unit kerja/prodi yang ada di } \\
\text { fakultas. }\end{array}$ \\
\hline 8 & NKD Top 5 & $\begin{array}{l}\text { Menampilkan nilai NKD tertinggi dan } \\
\text { terendah. Menghitung jumlah dosen } \\
\text { yang di kalkulasi, serta menghitung } \\
\text { rerata dari nilai NKD secara } \\
\text { keseluruhan. }\end{array}$ \\
\hline & List & $\begin{array}{l}\text { Menampilkan lima nilai NKD yang } \\
\text { tertinggi dari seluruh fakultas. }\end{array}$ \\
\hline
\end{tabular}

Tabel 5. Konten Informasi Prodi

\begin{tabular}{|c|l|l|l|}
\hline No & Konten Informasi & Output & \multicolumn{1}{c|}{ Perhitungan } \\
\hline 1 & Unit Kerja & List & $\begin{array}{l}\text { Menampilkan prodi yang telah dipilih } \\
\text { dengan masukan pengguna. }\end{array}$ \\
\hline 2 & Tahun Ajaran & List & $\begin{array}{l}\text { Menampilkan dalam periode satu tahun } \\
\text { dengan mengalkulasi 2 semester dalam } \\
1 \text { tahun ajaran. }\end{array}$ \\
\hline 3 & Dosen & $\begin{array}{l}\text { Scroll List } \\
\text { Bar }\end{array}$ & $\begin{array}{l}\text { Menampilkan list dosen sesuai di prodi } \\
\text { yang dipilih, ditambah pilihan } \\
\text { keseluruhan dosen untuk melihat } \\
\text { summary secara menyeluruh. }\end{array}$ \\
\hline 4 & Performa Kinerja & $\begin{array}{l}\text { Gauge } \\
\text { Chart }\end{array}$ & $\begin{array}{l}\text { Rata-rata kinerja dari tiap parameter } \\
\text { seluruh dosen se-prodi untuk tahun }\end{array}$ \\
\hline
\end{tabular}




\begin{tabular}{|c|l|l|l|}
\hline & & Tooltips & ajaran terkini. \\
\hline 5 & $\begin{array}{l}\text { History Performa } \\
\text { Kinerja }\end{array}$ & $\begin{array}{l}\text { Multiple } \\
\text { Line Chart }\end{array}$ & $\begin{array}{l}\text { Rata-rata kinerja dari tiap parameter } \\
\text { seluruh dosen prodi untuk tahun terkini } \\
\text { dan tiga tahun sebelumnya }\end{array}$ \\
\hline 6 & $\begin{array}{l}\text { Performa NKD } \\
\text { Semester }\end{array}$ & $\begin{array}{l}\text { Multiple } \\
\text { Bar Chart }\end{array}$ & $\begin{array}{l}\text { Rata-rata kinerja dari tiap parameter } \\
\text { untuk tiap semester pada tahun ajaran } \\
\text { terkini. }\end{array}$ \\
\hline 7 & $\begin{array}{l}\text { Statistik Kinerja Level } \\
\text { Fakultas }\end{array}$ & Text & $\begin{array}{l}\text { Menampilkan nilai NKD tertinggi dan } \\
\text { terendah. Menghitung jumlah dosen } \\
\text { yang di kalkulasi, serta menghitung } \\
\text { rerata dari nilai NKD secara } \\
\text { keseluruhan. }\end{array}$ \\
\hline 8 & NKD Top 5 & $\begin{array}{l}\text { Menampilkan lima nilai NKD yang } \\
\text { tertinggi dari seluruh prodi. }\end{array}$ \\
\hline
\end{tabular}

\section{Perancangan Prototipe Dashboard}

Setelah aktivitas identifikasi kebutuhan dan perencanaan konten dilakukan, maka tahap berikutnya adalah membuat purwarupa dari sistem dashboard view yang sesuai dengan metode data-centric. Sesuai dengan perencanaan konten pada Tabel 3 dan Tabel 4 terdapat dua buat tampilan utama yang ditujukan untuk fakultas dan prodi. Tampilan dashboard view untuk level fakultas secara global dapat dilihat pada Gambar 4 berikut.

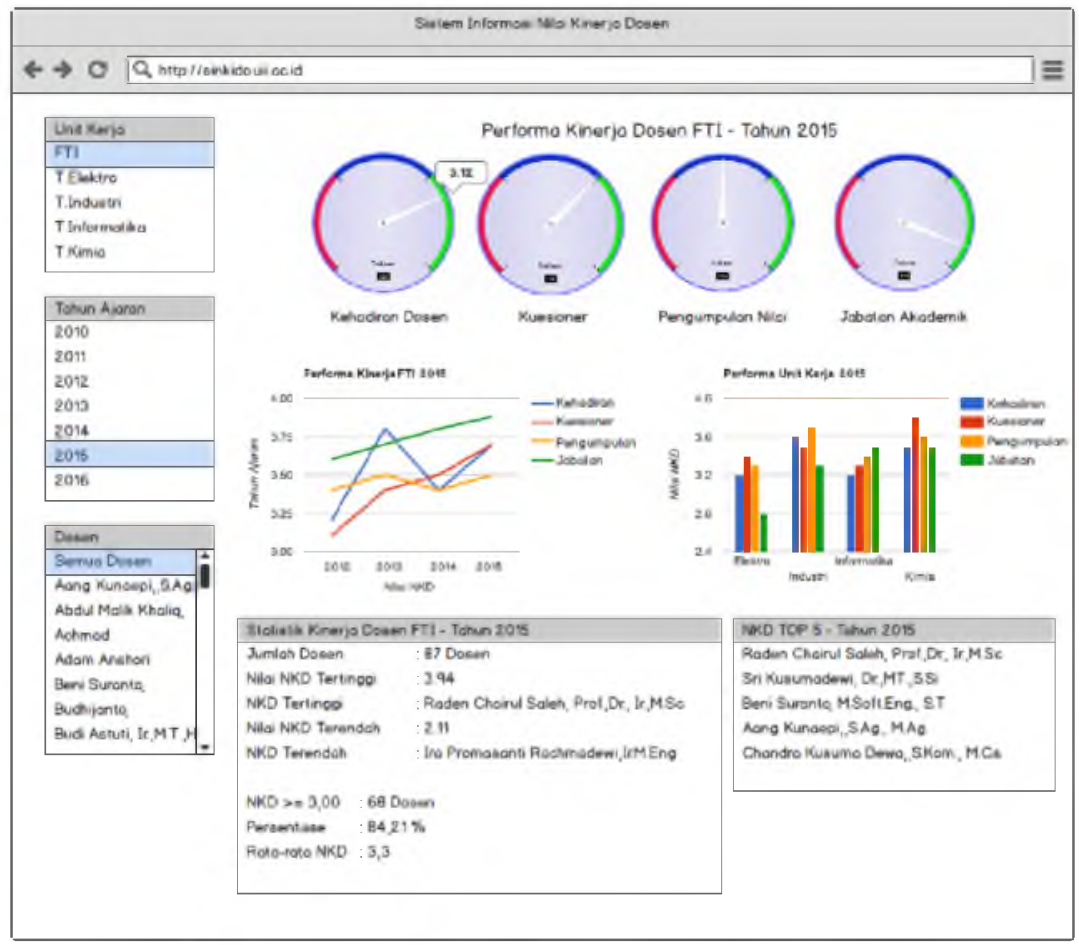

Gambar 4. Tampilan Prototype Dashboard Fakultas 
Kontrol navigasi yang ada pada tampilan dashboard didesain di sebelah kiri untuk kemudahan navigasi. Kontrol navigasi terdiri atas tiga pilihan yakni unit kerja, tahun ajaran, dan dosen. Navigasi ini bersifat dependensi, khususnya pada list dosen. Konten pada list dosen akan menyesuaikan pada pilihan list unit kerja. Dosen yang tertampil hanya dosen yang aktif pada unit kerja tersebut.

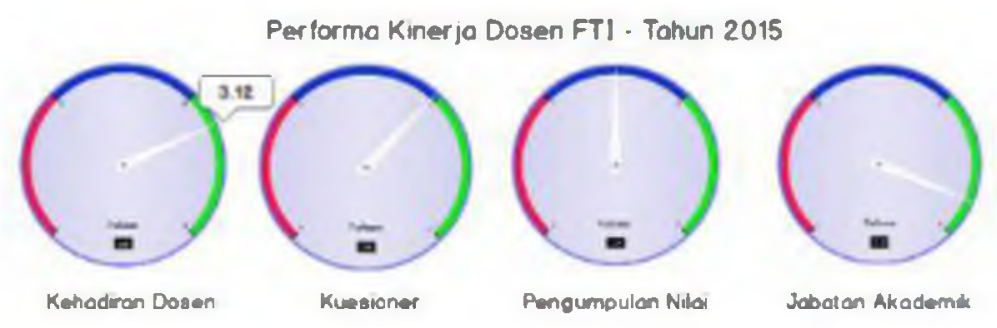

Gambar 5. Gauge Chart Untuk Performa NKD

Pada Gambar 5 gauge chart dipilih sebagai output pada tampilan kinerja secara keseluruhan. Diharapkan gauge chart dapat menampilkan informasi real time dengan baik, dorongan psikologis gauge chart dengan analogi speedometer kendaraan akan dapat memacu kinerja pengajar dalam meningkatkan kinerja pembelajarannya. Informasi ini hanya menampilkan rerata tiap parameter penilaian pada tahun aktif dan dapat melihat informasi tahun sebelumnya sesuai pilihan item pada list tahun.

Gauge chart tampilan kinerja akan dilengkapi fitur tooltips untuk kemudahan melihat angka kinerja sesuai dengan jarum penunjuk. Pewarnaan tiap section pada gauge chart juga dibagi menjadi tiga buah yakni merah, biru, dan hijau. Secara tidak langsung, jika penunjuk arah berada pada warna merah akan menjadi alert tersendiri.
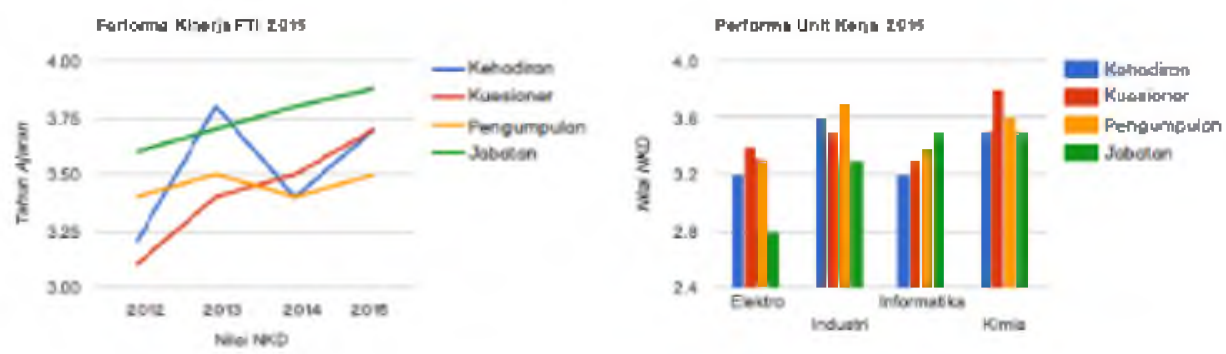

Gambar 6. Performa Unit Kerja Fakultas.

Pada Gambar 6 yang menunjukkan section berikutnya, dashboard akan menampilkan bentuk grafik multiple line dan multiple bar. Gambar multiple line menunjukan data historical dari performa kinerja dosen tiap kriteria. Data yang ditampilkan yaitu pada tahun terkini dan tiga tahun sebelumnya. Sedangkan pada gambar grafik multiple bar akan menggambarkan nilai NKD pada tiap unit kerja di fakultas.

Penggunaan warna yang berbeda merepresentasikan kriteria penilaian, untuk kemudahan pembacaan grafik maka disertakan pula legenda pada tiap grafik tersebut. Warna yang merepresentasikan kriteria digunakan secara konsisten pada kedua grafik tersebut karena konten informasi memiliki kemiripan yakni informasi tiap kriteria penilaian. 
Sedangkan pada section yang ditunjukkan pada Gambar 7 memberikan informasi statistik secara textual. Pemilihan tipe konten ini dikarenakan informasi yang dihasilkan akan berupa nama dosen.

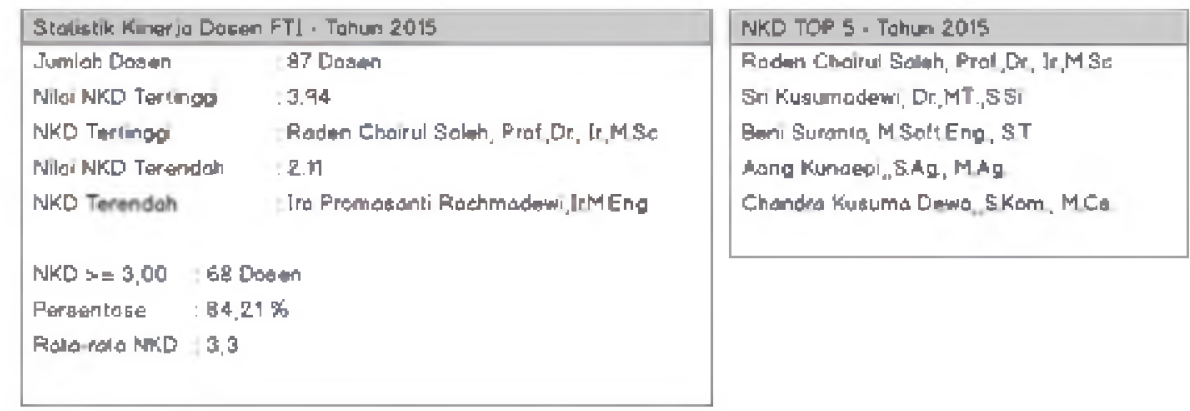

Gambar 7. Statistik Kinerja Textual Dashboard NKD

\section{Evaluasi Dashboard}

Review dashboard dilakukan dengan melakukan wawancara terhadap pengguna yang nantinya akan menggunakan dashboard information NKD yaitu pihak prodi dan fakultas. Parameter review dashboard dilakukan berdasarkan point-point karakteristik dashboard yang tercantum pada Tabel 1. Berikut ini ringkasan review yang dilakukan terhadap calon pengguna dashboard information NKD

Tabel 5. Ringkasan Review Dashboard NKD

\begin{tabular}{|c|l|l|l|}
\hline No & \multicolumn{1}{|c|}{ Karakteristik } & \multicolumn{1}{|c|}{ Prodi } & \multicolumn{1}{c|}{ Fakultas } \\
\hline 1 & Synergetic & $\begin{array}{l}\text { Informasi sudah cukup, dalam } \\
\text { satu layar sudah melihat semua. } \\
\text { Issues resolusi, apakah ada factor } \\
\text { scrolling. Menu lebih kecil agar } \\
\text { dan bs menggunakan auto } \\
\text { completion. Info yang di statistic } \\
\text { kurang pas karena menggunakan } \\
\text { teks. }\end{array}$ & $\begin{array}{l}\text { Penggunaan } \\
\text { speedometer chart } \\
\text { sudah cukup baik. } \\
\text { Hanya perlu diperjelas } \\
\text { warna jarum. Warna } \\
\text { indikator sebaiknya } \\
\text { merah-kuning hijau } \\
\text { (tidak merah-biru- } \\
\text { hijau) }\end{array}$ \\
\hline 2 & Monitor & $\begin{array}{l}\text { Sudah pas, tujuannya } \\
\text { menampilkan sesuai performa } \\
\text { dosen. }\end{array}$ & Sudah baik \\
\hline 3 & Accurate & Sudah sesuai & Sudah cukup \\
\hline 4 & Responsive & $\begin{array}{l}\text { Bisa ditunjukkan dengan } \\
\text { menggunakan warna warning } \\
\text { yang sesuai. }\end{array}$ & Sudah cukup \\
\hline 5 & Timely & $\begin{array}{l}\text { Tetap sesuai dengan range terkini } \\
\text { berdasarkan semester. }\end{array}$ & Cukup \\
\hline & Interactive & $\begin{array}{l}\text { Belum keliatan, informasi di Top } \\
\text { belum detail data-datanya. Data } \\
\text { rekapan statistic tidak }\end{array}$ & Belum kelihatan \\
\hline
\end{tabular}




\begin{tabular}{|c|c|c|c|}
\hline & & tervisualisasikan. & \\
\hline 7 & More Data history & Sudah sesuai. & Cukup \\
\hline 8 & Personalized & $\begin{array}{l}\text { Belum kelihatan. Ditambahkan } \\
\text { dashboard khusus untuk dosen }\end{array}$ & $\begin{array}{l}\text { Perlu dipisahkan } \\
\text { antara dosen tetap dan } \\
\text { dosen tidak tetap, } \\
\text { karena reward \& } \\
\text { punishment yang akan } \\
\text { diberlakukan juga } \\
\text { akan berbeda. Perlu } \\
\text { ditambahkan dosen } \\
\text { yang memiliki kinerja } \\
\text { terbaik secara } \\
\text { berturut2 dalam } \\
\text { beberapa semester } \\
\text { terakhir. }\end{array}$ \\
\hline 9 & Analytical & Belum kelihatan & $\begin{array}{l}\text { Kalau memberikan } \\
\text { fasilitas untuk analisis } \\
\text { sepertinya belum. } \\
\text { Namun cukup } \\
\text { membantu untuk } \\
\text { melakukan analisis } \\
\text { sebab akibat }\end{array}$ \\
\hline 10 & Collaborative & Belum ada. & Belum Ada \\
\hline 11 & Trackability & Filter sudah sesuai. & Sudah Cukup \\
\hline
\end{tabular}

\section{Kesimpulan}

Berdasarkan pendekatan pembuatan dashboard yang dipilih yakni pendekatan data-centric dan evaluasi prototype kepada pengguna ditemukan bahwa informasi dalam antarmuka yang dihasilkan dapat memuaskan penggunanya. Akan tetapi, faktor interactivity dan analytical masih belum memenuhi harapan pengguna, data-data yang belum tervisualisasikan dengan tepat. Ditemukan pula bahwa data dalam antarmuka dashboard belum dapat dijadikan sebagai fasilitas untuk analisis mendalam, akan tetapi dapat dimanfaatkan untuk membantu analisis sebab akibat. Secara garis besar, sesuai dengan objek pembuatan prototype dashboard di sistem NKD ini, pendekatan datacentric dapat diadopsi dengan baik dengan catatan memperhatikan lebih mendalam mengenai karakteristik interactivity dan analytical data.

\section{Daftar Pustaka}

[1] P. Republik Indonesia, Undang-Undang Republik Indonesia Tentang Guru Dan Dosen. 2005.

[2] P. Republik Indonesia, Peraturan Pemerintah Republik Indonesia. Indonesia, 2009.

[3] Direktorat Jenderal Pendidikan Tinggi, Pedoman Beban Kerja Dan Evaluasi Pelaksanaan Tridharma Pergurua Tinggi. 2010.

[4] S. Few, "Information Dashboard Design. The Effective Visual Communication Of Data. 3," 
Edv 161245, P. 211, 2006.

[5] N. H. Rasmussen, M. Bansal, And C. Y. Chen, Business Dashboards: A Visual Catalog For Design And Deployment. John Wiley \& Sons, 2009.

[6] S. Rahayu And B. M. Prasetyo, "Dashboard Information System Berbasis Key Performace Indicator," Vol. 2012, No. Semnasif, Pp. 82-87, 2012.

[7] S. Malik, Enterprise Dashboard - Design And Best Practices For It. Canada: John Wiley \& Sons, 2005.

[8] Novell, "Secure Enterprise Dashboard: A Key To Business Agility (White Paper)," 2004.

[9] E. R. Tufte, “The Visual Display Of Quantitative Information," 2001. [Online]. Available: Http:/Www.Amazon.Com/The-Visual-Display-Quantitative-Information/Dp/0961392142. [Accessed: 01-Feb-2016].

[10] S. K. Card, J. D. Mackinlay, And B. Shneiderman, Readings In Information Visualization: Using Vision To Think. 1999.

[11] T. Gonzalez, "User-Centric Approaches For Designing And Building Dashboards," 2008.

[12] E. Hariyanti, "Metodologi Pembangunan Dashboard Sebagai Alat Monitoring Kinerja Organisasi (Studi Kasus: Institut Teknologi Bandung)," 2008. 